\title{
Comparative Assessment of Biocontrol Agents (BGAs) and Chemical Insecticides on the Incidence and Management of Major Insect-Pests in Green Gram (Vigna radiata L.) in West Bengal, India
}

\author{
Prajna Pati* and Swarnali Battacharyya \\ Department of Plant Protection, Palli Siksha Bhavan, Visva Bharati, Santiniketan, \\ West Bengal, India \\ *Corresponding author
}

\begin{tabular}{|l|}
\hline Ke y w o r d s \\
Biocontrol Agents \\
(BGAs), \\
Insecticides, \\
Major insect-pests, \\
Green gram \\
\hline Article Info \\
\hline $\begin{array}{l}\text { Accepted: } \\
\text { 12 June } 2019 \\
\text { Available Online: } \\
\text { 10 July } 2019\end{array}$ \\
\hline
\end{tabular}

\section{Introduction}

India is the second most populated country only after China. The majority of the Indian population depends on agriculture for their livelihood. Post green era has resulted in tremendous increase in production and productivity of major crops which resulted in food and nutritional security of the nation.
A comparative assessment of spray efficacy of different bio-control agents such as Beauveria bassiana (Bb), Trichoderma viridae (Tv), Pseudomonas fluroscence (Pf), Verticillium lecanni (Vl), Metarhizium anisopliae (Ma) were tested in different combinations along with neem soil and chemical insecticides like imidachloprid and Acephate on major insect pest of green gram (Vigna radiata L). our results found that that, among the different treatments T-1 (Trichoderma viridae (Tv)+ Pseudomonas fluroscence $(\mathrm{Pf})+$ Beauveria basiana $(\mathrm{Bb})+$ Verticillium lecanni $(\mathrm{Vl})$ sprayed @ 5g/L of water significantly reduced the population of both white fly and pod bug infestation showing significant efficacy of biocontrol agents. Minimum insect count/plant of pod bug was observed in T-1 (1.17 insect/plant). T-1 showed minimum insects per plant (1.70 insect/plant) in case of white flies. Treatment-1( $\left.\mathrm{T}_{1}\right)$ recorded Maximum number of branches (10.44), maximum pods per plant (32.99), maximum pod length $(9.45 \mathrm{~cm})$, number of seeds per plant (10.10), pod weight (20.30 g) and test weight of the seeds (10 g) when compared to untreated control which recorded least numbers as compared to treated plots. T-1 was recorded with maximum activity of Phenols $(25.57 \mathrm{mg} / \mathrm{g}$ of leaf tissue), chlorophyll-a (3.7457mg/g of leaf tissue), chlorophyll-b (3.84 mg/g of leaf tissue), Total chlorophyll $(7.58 \mathrm{mg} / \mathrm{g}$ of leaf tissue) and total soluble sugars $(46.80 \mathrm{mg} / \mathrm{g}$ of leaf tissue). The least activities of all the biochemical factors were observed in untreated control. 
pulses do not requires high irrigation and other nutrients rather, their cultivation increases soil properties and enhances the production of subsequent crops especially cereals. Pulses being legumes fix atmospheric nitrogen into the soil hence, playing an important role in crop rotation, mixed farming and inter-cropping. The major pulses producing states in India are Madhya Pradesh (23\%), Uttar Pradesh (18\%), Maharashtra (14\%), Rajasthan (11\%), Andhra Pradesh (9\%), and Karnataka (6\%) where pulses are grown in arid and semi-arid regions as rain fed crops. About 80.15 per cent supply of pulses is contributed by these five states. Among the various pulses cultivated in India, Green gram (mung bean) occupies an important position.

Green gram (Vigna radiata Linn.) is the pulse crop being grown from antiquity. The crop is one of the most widely cultivated pulse crop after chickpea and pigeon pea. The crop has a high nutritional value adding various nutritional contents to the food every day. In recent years, the production and productivity of green gram is affected by many biotic stresses. Among them insects are major problem resulting in drastic reduction in yields and quality. The insects affect the crop in all the stages of crop. An estimated 200 insect pests that belong to 48 families in Coleoptera, Diptera, Hemiptera, Hymenoptera, Isoptera, Lepidoptera, Orthoptera, Thysanoptera, and 7 mites of the order Acarina are known to infest green gram all over the world (Reference). In India, among the 64 species of insect pests reported on green gram (Siddapaji et al., 1979), more than a dozen are of major importance, viz., Jassid, thrips, whitefly, semilooper, cutworm, Galerucid beetle tortricid caterpillar, pod borer, stem fly, green bug, cowpea aphid, and blue beetle are important (Borah, 1995a; Dar et al., 2002a). The Jassid, thrips and whitefly cause enormous damage by desaping the cell sap in large amount from tender plant parts. The whiteflies not only suck the sap of plants but also transmit Yellow Mosaic Virus (YMV) which causes 30-70 per cent yield loss (Marimuthanu et al., 1981). Substantial losses caused due to infestation of insect pests on Green gram are a matter of concern. Therefore efforts are needed to prevent them at minimum cost and without hazards to man or desirable components of his environment (Ruesink and Kogan, 1975).

Chemical insecticides are not economic and they are environmentally not safe. There are reports that many of the insects have developed resistance against major insecticides. The unidirectional, indiscriminate and non-judicious use of insecticides by the farmers led to the reduction in biodiversity of natural enemies, development of resistance, resurgence and secondary pest outbreaks with broad side contamination of food and ecosystem (Brown and Pal, 1971). To overcome this, eco friendly and economical management measures which are environmentally safe are need of the days (Geier, 1966; Smith and Van den Bosch, 1967). Thus biological control gained importance as we are using microbial agents of their products for the control of insects. Bio-fertilizers such as Rhizobium, Azotobacter, Azospirilium and blue green algae (BGA), phosphate solubilizing bacteria, Pseudomonas sp. have been in use from a long time to act as a biological line of defense against insect-pest and diseases of green gram. In the present investigation an effort was made to manage major insect pests of green gram in three different varieties using selected biofertlizers/bio control agents.

\section{Materials and Methods}

The present investigations were undertaken in the laboratory of Agricultural entomology and farm of the Department of Plant Protection, 
Institute of Agriculture, Visva-Bharati, and West Bengal during the year 2013-14 to 201415. The farm is situated at $23.39^{\circ} \mathrm{N}$ latitude, $87.42^{\circ} \mathrm{E}$ longitude and at an average altitude of $58.90 \mathrm{~m}$ above mean sea level. This belt has derived from alluvial rock and the laterisation process is still continuing. The physiographic characteristic is undulated with mild to steep gradient, and terraces of distinct top sequence. In high lands the soil consists of gravels and poor in organic matter. The soil properties are given in Table 1.

The experiment was undertaken to evaluate different biocontrol agents on the incidence and management of insect-pests of green gram under field condition. The experiment was conducted during 2013-2014. PDM-111 a popular variety was used for the experiment. The biofertilizers and biocontrol agents such as Rhizobium (URH 5), Phosphate solubilizing bacteria (UBPS 9) and Trichoderma viridae (UBT 18) procured from Uttar Banga Krishi Vishwavidyalaya (UBKV), Cooch Behar. The experiment was carried in simple randomized block design (RBD) with six treatments including control. Each treatment was replicated five times and the different treatments were allotted randomly in plots. The details of the treatments and biocontrol agents used in the experiment are given in Table 2. Before the sowing, the land was well irrigated and ploughed three times using tractor followed by leveling. The layout was made by making small experimental plots of $3 \mathrm{mt}$ X $4 \mathrm{mt}$ (12 $\mathrm{mt}^{2}$ ). There was adequate space for irrigation channel to maintain optimum soil moisture. The fertilizers were applied as per treatments considering 20:40:20kg of $\mathrm{N}: \mathrm{P}_{2} \mathrm{O}_{5}: \mathrm{K}_{2} \mathrm{O}$ has recommended dose. The fertilizer was applied at the time of sowing. Two weeding were done to keep the crop free from weeds. $1^{\text {st }}$ weeding was done 20-25days after sowing and second was 45 days after sowing. The observations such as incidence and damage due to different insects were recorded periodically. Harvesting was done manually and yield in different treatments were recorded. All the data was analyzed using MSTAT-C program. Different observations were calculated using following formulae.

Population reduction over control was worked by a procedure as laid out by Fleming and Retnakaran (1985) which is stated below.

1. Percent reduction in target insect population over control (Henderson \& Tilton1955)

Corrected per cent of Insect Population reduction $=$

$$
1 \text { - } \frac{\text { nin Co before treatment } x \text { in } T \text { after treatment }}{n \text { in Co after treatment } x \text { in } \text { in }_{\text {before treatment }}} \times 100
$$

Where, $\mathrm{n}=$.insect population; $\mathrm{T}=$ Treated; $\mathrm{Co}$ $=$ Control

Simultaneously the Yield data of each treatment was recorded and the data of two spraying were averaged before analysis. Percent protection over control was worked out by slight modification of Abbott's (1925) formula

Per cent Protection over control $=$

$$
\begin{array}{cc}
\begin{array}{c}
\text { Per cent Protection } \\
\text { in treatment }
\end{array} & \begin{array}{c}
\text { Per cent Protection } \\
\text { in control }
\end{array}
\end{array}
$$

$$
100 \text { - \% Protection in control }
$$

\section{Results and Discussion}

The present investigation was undertaken to study the effect of application of various bicontrol agents on the incidence and management of insect-pests of green gram. The results are presented hereunder. The effect of all the biocontrol agents was significant. From table 3 it is clear that, in 
case of pod bug, the maximum pre-count of insects was observed in control during all the three observations. i.e., 3, 7 and 14 days after spraying. The mean minimum insect count was observed in imidachloprid treatment ( $\mathrm{T}$ 4) which recorded 0.87 insects/plant when compared to control which recorded 2.04 insects/plant. Whereas, among the biocontrol treatments, minimum insect count/plant was observed in T-1 (1.17 insect/plant). Overall efficacy of biocontrol agents was superior compared to control. Maximum efficacy over control was observed in T-4 (61.76\%) followed by $\mathrm{T}-1$ with $42.64 \%$ reduction over control. In case of whitefly population (Table 4 ), the treatment 4 (T-4) recorded minimum number of insects (1.59 insects/plant) when compared to untreated control (3.97 insect/plant). Among the biocontrol agents, the $\mathrm{T}-1$ shown minimum insects per plant (1.70 insect/plant). Maximum overall efficacy was observed in T-4 (59.94\%) followed by T1 with $56.67 \%$ efficacy over control. From these observations, it is clear that the efficacy of biocontrol agents in controlling both pod bug and Whitefly was varied among the treatments and can be utilized as safer management practice by avoiding chemical insecticides. The growth and yield parameters such as plant height, number of branches, and number of pods/plant, pod length, number of seeds per pod, pod dry weight and test weight of the seeds were recorded (Table 5).

Table.1 Physical and chemical properties of the soil of the experimental plot

\begin{tabular}{|c|c|c|c|c|c|c|c|c|}
\hline Propert & $\begin{array}{l}\text { Sand } \\
(\%)\end{array}$ & Silt (\%) & $\begin{array}{l}\text { Clay } \\
(\%)\end{array}$ & pH & $\begin{array}{l}\text { Organic } \\
\text { carbon }(\%)\end{array}$ & $\begin{array}{l}\text { Available } \\
\text { N(Kg/ha) }\end{array}$ & $\begin{array}{l}\text { Available } \\
\mathrm{P}(\mathrm{Kg} / \mathrm{ha})\end{array}$ & $\begin{array}{l}\text { Available } \\
\text { K(Kg/ha) }\end{array}$ \\
\hline Values & 75.6 & 14.8 & 9.6 & 5.65 & 0.33 & 197.35 & 17.43 & 141.50 \\
\hline
\end{tabular}

Table.2 Details of the biocontrol agents used in the experiment.

\begin{tabular}{|c|c|c|c|}
\hline Treatment & Name & Trade Name & Source \\
\hline T1 & $\begin{array}{l}\text { Trichoderma viridae }(\mathrm{Tv})+ \\
\text { Pseudomonas fluroscence } \\
(\mathrm{Pf})+\text { Beauveria basiana }(\mathrm{Bb})+ \\
\text { Verticillium lecanni }(\mathrm{Vl})\end{array}$ & $\begin{array}{l}\text { (Tv)- UBT } 18 \\
\text { (Pf)- VPF } 1 \\
\text { (Bb)- Bio power } \\
\text { (V1)-Bio catch }\end{array}$ & $\begin{array}{l}\text { UBKV, CoochBehar } \\
\text { UBKV, CoochBehar } \\
\text { T stanes and company Ltd. } \\
\text { T stanes and company Ltd. }\end{array}$ \\
\hline $\mathbf{T 2}$ & $\begin{array}{l}\text { Pseudomonas fluorescens } \\
\text { (Pf)+Trichoderma viridae } \\
\text { (Tv)+Metarhizium anisopliae } \\
\text { (Ma)+Verticillium lecani }(\mathrm{Vl})\end{array}$ & $\begin{array}{l}\text { (Pf)-VPF } 1 \\
\text { (Tv)-UBT } 18 \\
\text { (Ma)-Bio magic } \\
\text { (Vl)-Bio catch }\end{array}$ & $\begin{array}{l}\text { UBKV, CoochBehar } \\
\text { UBKV, CoochBehar } \\
\text { T stanes and company Ltd. } \\
\text { T stanes and company Ltd. }\end{array}$ \\
\hline T3 & $\begin{array}{l}\text { Trichoderma viridae } \\
(\mathrm{Tv})+\text { Pseudomonas } \\
\text { fluorescens }(\mathrm{Pf})+\text { Verticillium } \\
\text { lecani( } \mathrm{Vl})+\mathrm{Neem} \text { oil }\end{array}$ & $\begin{array}{l}\text { (Tv)-UBT } 18 \\
\text { (Pf)-VPF } 1 \\
\text { (Vl)-Bio catch }\end{array}$ & $\begin{array}{l}\text { UBKV, CoochBehar } \\
\text { UBKV, CoochBehar } \\
\text { T stanes and company Ltd. }\end{array}$ \\
\hline T4 & Imidachloprid & Leopard70WG & Willowood Chemicals Pvt. Ltd. \\
\hline T5 & Acephate & ASSAULT & Modern insecticide ltd.. \\
\hline T6 & Control & ------------- & ----------------- \\
\hline
\end{tabular}


Table.3 Per cent reduction in the incidence of pod bug after spraying of some bio-pesticides and insecticidal molecules

\begin{tabular}{|c|c|c|c|c|c|c|c|}
\hline Treatments & Dose & $\begin{array}{c}\text { Pre-count } \\
\text { insect/Plant }\end{array}$ & 3 DAS & 7 DAS & 14 DAS & Mean & $\begin{array}{c}\text { Mean efficacy over } \\
\text { control (\%) }\end{array}$ \\
\hline T-1 & $5 \mathrm{~g} / \mathrm{L}$ & $21.10(4.70)$ & $19.00(4.47)$ & $11.63(3.55)$ & $6.31(2.70)$ & 12.31 & 52.34 \\
\hline T-2 & $5 \mathrm{~g} / \mathrm{L}$ & $20.19(4.60)$ & $18.63(4.43)$ & $12.88(3.72)$ & $8.06(3.01)$ & 13.19 & 48.94 \\
\hline T-3 & $5 \mathrm{~g} / \mathrm{L}$ & $20.71(4.66)$ & $18.38(4.40)$ & $14.56(3.94)$ & $11.25(3.50)$ & 14.73 & 42.97 \\
\hline T-4 & $0.2 \mathrm{~mL} / \mathrm{L}$ & $21.76(4.77)$ & $19.94(4.58)$ & $13.94(3.86)$ & $9.94(3.31)$ & 14.60 & 43.48 \\
\hline T-5 & $1 \mathrm{~g} / \mathrm{L}$ & $22.41(4.84)$ & $18.28(4.39)$ & $12.63(3.69)$ & $10.44(3.38)$ & 13.78 & 46.65 \\
\hline T-6 & Water Spray & $21.80(4.77)$ & $22.56(4.85)$ & $26.31(5.23)$ & $28.63(5.44)$ & 25.83 & 52.34 \\
\hline $\operatorname{SEm}( \pm)$ & & 0.05 & 0.08 & 0.11 & 0.012 & & \\
\hline $\mathrm{CD}=0.05$ & & 0.16 & 0.25 & 0.34 & 0.036 & & \\
\hline
\end{tabular}

$\mathrm{T}_{1}$ : Trichoderma viridae $(\mathrm{Tv})+$ Pseudomonas fluorescens $(\mathrm{Pf})+$ Beauveria bassiana $(\mathrm{Bb})+$ Verticillium lecanii $(\mathrm{Vl}) \mathrm{T}_{2}$ : Pseudomonas fluroscence $(\mathrm{Pf})+$ Trichoderma viridae $(\mathrm{Tv})+$ Metarrhizium anisopliae $(\mathrm{Ml})+$ Verticillium lecanii $(\mathrm{Vl}) \mathrm{T}_{3}:$ Trichoderma viridae $(\mathrm{Tv})+$ Pseudomonas fluorescens $(\mathrm{Pf})+$ Verticillium lecanii $(\mathrm{Vl})+\mathrm{Neem} \mathrm{T}_{4}$ : Imidachloprid $17.8 \% \mathrm{SL}, \mathrm{T}_{5}$ : Acephate $75 \% \mathrm{SP}, \mathrm{T}_{6}$ : Control

DAS=Days after spraying

* Data in the parentheses are square root transformed value

Table.4 Per cent reduction in the incidence of white fly after spraying of some bio-pesticides and insecticides

\begin{tabular}{|l|l|c|c|c|c|c|c|}
\hline Treatments & Dose & $\begin{array}{c}\text { Precount } \\
\text { Insect/Plant }\end{array}$ & 3DAS & 7DAS & 14DAS & $\begin{array}{c}\text { Average Overall } \\
\text { efficacy }\end{array}$ & $\begin{array}{c}\text { Efficacy over } \\
\text { control }\end{array}$ \\
\hline T-1 & $5 \mathrm{~g} / \mathrm{L}$ & $2.90(1.836)^{*}$ & $1.70(1.490)$ & $1.42(1.380)$ & $2.00(1.578)$ & $1.70(1.480)$ & $56.67 \%$ \\
\hline T-2 & $5 \mathrm{~g} / \mathrm{L}$ & $2.70(1.782)$ & $2.02(1.584)$ & $1.88(1.540)$ & $2.16(1.628)$ & $2.02(1.584)$ \\
\hline T-3 & $5 \mathrm{~g} / \mathrm{L}$ & $2.80(1.812)$ & $2.12(1.616)$ & $2.26(1.660)$ & $2.32(1.676)$ & $2.23(1.650)$ \\
\hline T-4 & $0.2 \mathrm{~mL} / \mathrm{L}$ & $3.00(1.866)$ & $1.16(1.282)$ & $1.06(1.240)$ & $2.56(1.746)$ & $1.59(1.422)$ & $43.11 \%$ \\
\hline T-5 & $1 \mathrm{~g} / \mathrm{L}$ & $3.04(1.872)$ & $2.00(1.576)$ & $2.34(1.680)$ & $3.32(1.948)$ & $2.55(1.730)$ \\
\hline T-6 & Water Spray & $3.12(1.892)$ & $3.76(2.06)$ & $3.94(2.100)$ & $4.22(2.166)$ & $3.97(2.100)$ & $35.94 \%$ \\
\hline SEm $( \pm)$ & & & $\mathbf{0 . 0 2 8}$ & $\mathbf{0 . 0 6 2}$ & $\mathbf{0 . 0 2 1}$ & \\
\hline CD $=\mathbf{0 . 0 5}$ & & & $\mathbf{0 . 0 8 3}$ & $\mathbf{0 . 1 8 3}$ & $\mathbf{0 . 0 6 2}$ & \\
\hline
\end{tabular}

$\mathrm{T}_{1}$ : Trichoderma viridae $(\mathrm{Tv})+$ Pseudomonas fluorescens $(\mathrm{Pf})+$ Beauveria bassiana $(\mathrm{Bb})+$ Verticillium lecanii $(\mathrm{Vl}) \mathrm{T}_{2}$ : Pseudomonas fluroscence $(\mathrm{Pf})+$ Trichoderma viridae $(\mathrm{Tv})+$ Metarrhizium anisopliae $(\mathrm{Ml})+$ Verticillium lecanii $(\mathrm{Vl}) \mathrm{T}_{3}$ : Trichoderma viridae $(\mathrm{Tv})+$ Pseudomonas fluorescens $(\mathrm{Pf})+$ Verticillium lecanii $(\mathrm{Vl})+\mathrm{Neem} \quad \mathrm{T}_{4}$ : Imidachloprid $17.8 \% \mathrm{SL}, \mathrm{T}_{5}$ : Acephate $75 \% \mathrm{SP}, \mathrm{T}_{6}$ : Control

DAS=Days after spraying

* Data in the parentheses are square root transformed value 
Table.5 Effect of foliar application of biocontrol agents on growth and yield parameters as influenced white fly and pod bug infection

\begin{tabular}{|c|c|c|c|c|c|c|c|c|}
\hline Treatments & Dose & $\begin{array}{c}\text { Plant ht.(in } \\
\text { cm) }\end{array}$ & $\begin{array}{c}\text { No of } \\
\text { branches }\end{array}$ & $\begin{array}{l}\text { No. of pod } \\
\text { per plant }\end{array}$ & $\begin{array}{l}\text { Length of pod } \\
\quad \text { (in } \mathrm{cm})\end{array}$ & $\begin{array}{c}\text { No. of seed per } \\
\text { pod }\end{array}$ & Pod wt (in gm) & $\begin{array}{c}100 \text { seed } \\
\text { weight }(g)\end{array}$ \\
\hline T-1 & $5 \mathrm{~g} / \mathrm{L}$ & $27.43(5.33)^{*}$ & $10.44(3.38)$ & $32.99(5.83)$ & $9.45(3.23)$ & $10.10(3.33)$ & $20.30(4.62)$ & 10.50 \\
\hline T-2 & $5 \mathrm{~g} / \mathrm{L}$ & $19.44(4.52)$ & $7.13(2.85)$ & $22.69(4.87)$ & $7.06(2.84)$ & $7.21(2.87)$ & $15.75(4.09)$ & 7.25 \\
\hline T-3 & $5 \mathrm{~g} / \mathrm{L}$ & $23.74(4.97)$ & $9.44(3.23)$ & $27.56(5.34)$ & $9.08(3.17)$ & $8.85(3.14)$ & $18.00(4.36)$ & 8.00 \\
\hline T-4 & $0.2 \mathrm{~mL} / \mathrm{L}$ & $20.51(4.64)$ & $8.40(3.07)$ & $24.48(5.05)$ & $8.55(3.09)$ & $7.38(2.89)$ & $16.99(4.24)$ & 6.50 \\
\hline T-5 & $1 \mathrm{~g} / \mathrm{L}$ & $18.81(4.45)$ & $6.96(2.82)$ & $17.94(4.35)$ & $6.44(2.73)$ & $6.50(2.74)$ & $14.59(3.95)$ & 6.00 \\
\hline T-6 & Water Spray & $16.63(4.20)$ & $5.44(2.54)$ & $16.49(4.18)$ & $5.41(2.53)$ & $5.69(2.59)$ & $10.88(3.45)$ & 5.50 \\
\hline $\operatorname{SEm}( \pm)$ & & 0.110 & 0.09 & 0.070 & 0.06 & 0.09 & 0.09 & \\
\hline $\mathrm{CD}=0.05$ & & 0.35 & 0.26 & 0.220 & 0.19 & 0.26 & 0.26 & \\
\hline
\end{tabular}

$\mathrm{T}_{1}$ : Trichoderma viridae $(\mathrm{Tv})+$ Pseudomonas fluorescens $(\mathrm{Pf})+$ Beauveria bassiana $(\mathrm{Bb})+$ Verticillium lecanii $(\mathrm{Vl}) \mathrm{T}_{2}$ : Pseudomonas fluroscence $(\mathrm{Pf})+$ Trichoderma viridae $(\mathrm{Tv})+$ Metarrhizium anisopliae $(\mathrm{Ml})+$ Verticillium lecanii $(\mathrm{Vl}) \mathrm{T}_{3}$ : Trichoderma viridae $(\mathrm{Tv})+$ Pseudomonas fluorescens $(\mathrm{Pf})+$ Verticillium lecanii $(\mathrm{Vl})+$ Neem $\quad \mathrm{T}_{4}$ : Imidachloprid $17.8 \% \mathrm{SL}, \mathrm{T}_{5}$ : Acephate $75 \% \mathrm{SP}, \mathrm{T}_{6}$ : Control

DAS=Days after spraying

* Data in the parentheses are square root transformed value

Table.6 Effect of foliar application of biocontrol agents on biochemical activities as influenced white fly and pod bug infection

\begin{tabular}{|c|c|c|c|c|c|c|}
\hline Treatments & Dose & $\begin{array}{l}\text { Total Phenols } \\
\text { (mg/g of tissue) }\end{array}$ & $\begin{array}{l}\text { Chlorophyll-a } \\
\text { (mg/g of tissue) }\end{array}$ & $\begin{array}{l}\text { Chlorophyll-b } \\
\text { (mg/g of tissue }\end{array}$ & $\begin{array}{l}\text { Total Chlorophyll (a+b) } \\
\text { (mg/g of tissue) }\end{array}$ & $\begin{array}{l}\text { Total soluble sugars } \\
\text { (mg/g of tissue) }\end{array}$ \\
\hline T-1 & $5 \mathrm{~g} / \mathrm{L}$ & $25.57(5.16)$ & $3.74(2.17)$ & $3.84(2.20)$ & $7.58(2.93)$ & $46.89(6.92)$ \\
\hline T-2 & $5 \mathrm{~g} / \mathrm{L}$ & $14.26(3.91)$ & $2.408(1.84)$ & $2.67(1.91)$ & $5.08(2.46)$ & $37.21(6.18)$ \\
\hline T-3 & $5 \mathrm{~g} / \mathrm{L}$ & $17.98(4.36)$ & $3.53(2.12)$ & $3.31(2.07)$ & $6.84(2.80)$ & $45.73(6.84)$ \\
\hline T-4 & $0.2 \mathrm{~mL} / \mathrm{L}$ & $15.89(4.11)$ & $3.48(2.11)$ & $3.29(2.07)$ & $6.78(2.79)$ & $41.15(6.49)$ \\
\hline T-5 & $1 \mathrm{~g} / \mathrm{L}$ & $11.72(3.57)$ & $2.00(1.73)$ & $1.99(1.73)$ & $4.00(2.23)$ & $32.81(5.82)$ \\
\hline T-6 & Water Spray & $8.56(3.09)$ & $1.45(1.56)$ & $1.48(1.57)$ & $2.94(1.98)$ & $27.40(5.33)$ \\
\hline $\operatorname{SEm}( \pm)$ & & 2.33 & 0.03 & 0.04 & 0.03 & 0.01 \\
\hline $\mathrm{CD}=\mathbf{0 . 0 5}$ & & 7.02 & 0.09 & 0.11 & 0.10 & 0.04 \\
\hline
\end{tabular}

$\mathrm{T}_{1}$ : Trichoderma viridae $(\mathrm{Tv})+$ Pseudomonas fluorescens $(\mathrm{Pf})+$ Beauveria bassiana $(\mathrm{Bb})+$ Verticillium lecanii $(\mathrm{Vl}) \mathrm{T}_{2}:$ Pseudomonas fluorescens $(\mathrm{Pf})+$ Trichoderma viridae $(\mathrm{Tv})+$ Metarrhizium anisopliae $(\mathrm{Ml})+$ Verticillium lecanii $(\mathrm{Vl}) \mathrm{T}_{3}$ : Trichoderma viridae $(\mathrm{Tv})+$ Pseudomonas fluorescens $(\mathrm{Pf})+$ Verticillium lecanii $(\mathrm{Vl})+$ Neem $\mathrm{T}_{4}$ : Imidachloprid $17.8 \% \mathrm{SL}, \mathrm{T}_{5}$ : Acephate $75 \% \mathrm{SP}, \mathrm{T}_{6}$ : Control

DAS=Days after spraying

* Data in the parentheses are square root transformed value. 
Significant differences were observed among the treatments in efficacy in improving growth and yield parameters. Maximum plant height was recorded in $\mathrm{T}-1 \quad(27.43 \mathrm{~cm})$ followed by T-3 $(23.74 \mathrm{~cm})$. Whereas untreated control recorded only $16.63 \mathrm{~cm}$ plant height. Similar trend was observed in other parameters also. Treatment- $1\left(\mathrm{~T}_{1}\right)$ recorded Maximum number of branches (10.44), maximum pods per plant (32.99), maximum pod length $(9.45 \mathrm{~cm})$, number of seeds per plant (10.10), pod weight $(20.30 \mathrm{~g})$ and test weight of the seeds $(10 \mathrm{~g})$ when compared to untreated control which recorded least numbers as compared to treated plots. Biochemical factors such as phenols, Chlorophyll and total soluble sugars were estimated after 7 days of spraying (Table 6). Among the treatments, T-1 recorded maximum activity of Phenols $(25.57 \mathrm{mg} / \mathrm{g}$ of leaf tissue), chlorophyll-a $(3.7457 \mathrm{mg} / \mathrm{g}$ of leaf tissue), chlorophyll-b (3.84 mg/g of leaf tissue), Total chlorophyll $(7.58 \mathrm{mg} / \mathrm{g}$ of leaf tissue) and total soluble sugars $(46.80 \mathrm{mg} / \mathrm{g}$ of leaf tissue). The least activities of all the biochemical factors were observed in untreated control. From above observations it is clear that, application of biocontrol agents not only minimized insect-pest incidence in green gram, but also significantly increased growth and yield parameters. Significant increased activities of biochemical factors also observed all the biocontrol treatments when compared to control.

Insects, like many other living organisms are susceptible to a variety of diseases caused by bacteria, fungi, viruses and protozoans. These micro organisms are exploited for their beneficial role in management of various harmful insects that cause damage in many agricultural and horticultural crops (Ramanujam et al., 2013). This is called as biological control where, we use microbial agents or their products called as secondary metabolites to act against harmful insects. The most successfully utilized biocontrol agent is Bacillus thuringiensis (Bt) which is used extensively for management of certain lepidopteran pests. Entomopathogenic fungi like Beauveria bassiana, B. brongniartii, Metarhizium anisopliae, M. anisopliae var. acridium, Lecanicillium spp., Hirsutella thompsonii, Nomuraea rileyi and Isaria fumosorosea are gaining importance in the crop pest control in recent years due to the simpler, easier and cheaper mass production techniques. Environmental humidity and temperature play an important role in the infection and sporulation of these fungi and as such they are highly suitable during cool and humid cropping seasons (de Faria et al., 2007; Ramanujam et al., 2013). In this experiment, we have reported that, spraying of biological control agents in green gram significantly reduced the population of white fly and pod borer. There was not only increase in growth parameters, but also significantly increased activities of defense enzymes were recorded in all the biocontrol treatments when compared to chemical treatment and untreated check.

There are reports of management of insect pests in various crops such. Hazarika and Puzari (1997) reported that, Spraying of $B$. bassiana spore suspension 10 million spore/mL controls Rice Hispa (Dicladispa armigera). Spraying $B$. bassiana spore suspension@1x107 spores/mL containing sunflower oil $(0.1 \%)$ and 0.1 per cent wetting agent during monsoon reduced 50-60 per cent berry borer incidence in coffee (Annon, 2001). Spraying oil suspension of B. bassiana $(200 \mathrm{mg} / \mathrm{L})$ controls sunflower Helicoverpa armigera (Devi and Hari, 2009). Metarhizium anisopliae conidia in an oil formulation was effective in reducing $66.58 \%$ of pigeon pea pod borer $(H$. armigera) when compared to $62.58 \%$ with endosulfan in Maharashtra (Nahar et al., 2004). Jayaraj (1989) reported that, spraying spores of Verticilium lecanii @ 
$16 \times 10^{6}$ spore/mL along with Tween-80 twice at 2 weeks interval caused 97.6 per cent mortality of coffee green scale (Coccus viridis). Similar results were found by Singh et al., (1995) they reported that, Spraying of spores $2 \times 10^{6}$ spores $/ \mathrm{mL}$ along with $0.005 \%$ quinolphos and 0.05 per cent Teepol was found highly effective killing $95.58 \%$ of citrus green scales, in coffee and citrus respectively. Similarly spraying of $V$ lecanii spores (@ $10^{6}$ spores $/ \mathrm{mL}$ ), there was a significant reduction aphid infestation at 10 DAS in Indian mustard and rapeseed as reported by Rana et al., (2002). The results of the present study are similar to the finding of Khuroo et al., (2003) which proved that the spraying of imidacloprid reduced the white fly population and gave the highest average yield. The mode of action of these biological control agents are varied.

It is achieved when sufficient infective propagules (generally conidia) contact a susceptible host and conditions are suitable for a lethal mycosis to develop. Fungi have been applied for soil pest control by direct incorporation of conidia, mycelial pellets, microsclerotia or inert or nutrient-based granules containing fungal propagules (conidia or mycelia) (Ansari et al., 2006b, Jaronski and Jackson, 2008), whereas foliarfeeding pests have typically been targeted by sprays of formulated conidia (Jaronski, 2010). Virulent isolates generally express an abundance of spore-bound proteases, efficiently produce and release exoenzymes during cuticular penetration, and generate toxins as the fungus colonizes the host (Vey et al., 2001; Khan et al., 2012). Selecting superior strains exhibiting these characteristics, or manipulating isolates to promote these traits, has been seen as a way of overcoming what is often considered a significant impediment to their wider use, i.e., fungi kill their hosts too slowly. In conclusion, biological control of insect pests is safe and ecofriendly. They not only reduce the cost on chemicals but also create a healthy environment for the growth and multiplication of natural enemies. Entomopathogens offer a great potential for pest management. Some of the species that have been most intensively investigated for mycoinsecticides in the crop pest control include Beauveria bassiana, $B$. brongniartii, Metarhizium anisopliae, $M$. anisopliae var. acridium, Lecanicillium spp., (previously Verticillium lecanii), Hirsutella thompsonii, Nomuraea rileyi and Isaria fumosorosea (previously Paecilomyces fumosoroseus) are commercially available with different trade names. They can be utilized for effective and ecofriendly integrated pest management.

\section{Acknowledgements}

The author thanks Head, Division of Plant Protection, Palli Siksha Bhavan, ViswaBharati, Shanthiniketan for providing laboratory and field facilities during the experiments.

\section{References}

Anonymous (2001) Biological control of coffee berry borer. In: (Eds: Sridharan K, Vinod Kumar PB and Prakasan CB), Coffee Berry Borer in India Central Coffee Research Institute, Coffee Research Station Post, Chickmagalur District, Karnataka. pp 45-57.

Ansari, M.A., Shah, F.A., Whittaker, M., Prasad, M., Butt, T.M., 2006b. Control of western flower thrips (Frankliniella occidentalis) pupae with Metarhizium anisopliae in peat and peat alternative growing media. Biol. Control 40, 293297.

Borah, R. K. 1995a. Insect pest complex in summer green gram (Vigna radiata L.). Annals of Agriculture Research, 16 (1): 91-92. 
Brown, Anthony William Aldridge, Pal, Rajindar \& World Health Organization . (1971). Insecticide resistance in arthropods / A. W. A. Brown, R. Pal, 2nd ed. World Health Organization.

Dar, M. H.; Rizvi, P. Q. and Naqvi, N. A. 2002a. Insect pest complex and its succession on mungbean and urdbean. Indian Journal of Pulses Research, 15 (2): 204.

Faria MR and Wraight S (2007) Mycoinsecticides and Mycoherbicides: A comprehensive list with worldwide coverage and international classification of formulation types. Biol Control 43 (2007) 237- 256.

Geier PW (1966) Management of Insect Pests, Annual Review of Entomology. $11: 471-490$

https://doi.org/10.1146/annurev.en.11.0 10166.002351

Hazarika LK and Puzari KC (1997) Field efficacy of white muscardine fungus (Beaveria bassiana) on rice hispa (Dicladispa armigera). Indian J Agr Sci 67: 463-465.

Jaronski, S.T., 2010. Ecological factors in the inundative use of fungal entomopathogens. Biocontrol 55, 159185.

Jaronski, S.T., Jackson, M.A., 2008. Efficacy of Metarhizium anisopliae microsclerotial granules. Biocontrol Sci. Technol. 18, 849-863.

Jayaraj S (1989) Integrated management of coffee green scale Coccus viridis (Green) (Homoptera; Coccidae) J Plantation Crops 16 (1989) 195-201

Khan, S., Guo, L., Maimaiti, Y., Mijit, M., Qiu, D., 2012. Entomopathogenic fungi as microbial biocontrol agents. Mol. Plant Breed. 3, 63-79.

Khuroo, M. S., Khare, C. P., Tiwari, P. K. and Shrivastava, S. K. (2003) Possibilities of imidacloprid incorporation for the management of white fly Bemisia tabaci Gann. on chilli. Environment and Ecology 21(1), 214-217.

Nahar, P.B., Kulkarni, S.A., Kulye, M.S., Chavan, S.B., Kulkarni, G., Rajendran, A., Yadav, P.D., Shouche, Y., Deshpande, M.V., 2008. Effect of repeated in vitro sub culturing on the virulence of Metarhizium anisopliae against Helicoverpa armigera (Lepidoptera: Noctuidae). Biocontrol Sci. Technol. 18, 337-355.

Ramanujam B, Rangeswaran R, Sivakumar G, Mohan M and Yandigeri (2013) Management of Insect Pests by Microorganisms. Proc Indian Natn Sci Acad 80 No. 2 June 2014 Spl. Sec. pp. 455-471.

Rana JS, Singh D (2002) Entomopathogenic fungi Verticillium lecanii (Zimm): a potential biocontrol agent against mustard aphid, Lipaphis erysimi (Kalt) on rapeseed mustard. Cruciferous News Letter.24:97-98.

Ruesink, W. G. and Kogan, M. 1975. The quantitative basis of pest management: Sampling and Measuring. Introduction to Insect Pest Management. Metcalf, $\mathrm{R}$. L. and Luckmann, W. R. Eds. Pub. John Willey and Sons, New York: 309-351.

Siddapaji, C.; Gowda, N. G. and Rao, G. N. G. 1979. Millipede- a new enemy of moong crop. Current Research, 8 (7): 114-116.

Singh SP (1995) use of entomopathogenic fungus, Verticilium lecanii (Zimm) viegas, insecticides and their combination for the control of green scale, Coccus viridis (Green) Indian J Hort 52 (1995) 259-26.

Smith, R. F., and R. van den Bosch. 1967. Integrated control. Chap. 9. In Pest Control: Biological, Physical and Selected Chemical Methods, W. W. Kilgore and R. L. Doutt (eds.). Academic Press, N. Y. 477 pp.

Vey, A., Hoagland, R.E., Butt, T.M., 2001. 
Toxic metabolites of fungal biocontrol agents. In: Butt, T., Jackson, C., Magan, N. (Eds.), Fungi as Biocontrol Agents Progress, Problems and Potential. CABI Press, Wallingford, UK, pp. 311-346. Vimala Devi PS and Hari PP (2009) Baevaria bassiana suspension concentrate-A mycoinsecticide for the management of Helicoverpa armigera (Hubner), J Biol Control 23 (2009) 403-408.

\section{How to cite this article:}

Prajna Pati and Swarnali Battacharyya. 2019. Comparative Assessment of Biocontrol Agents (BGAs) and Chemical Insecticides on the Incidence and Management of Major Insect-Pests in Green Gram (Vigna radiata L.) in West Bengal. Int.J.Curr.Microbiol.App.Sci. 8(07): 15781587. doi: https://doi.org/10.20546/ijcmas.2019.807.188 